\title{
Prólogo a la primera edición
}

La «Brockhaus ABC Biochemie» se publicó por primera vez en Leipzig en 1976, siguiéndole la segunda edición en 1981. Cuando decidimos traducir este libro, basado en la segunda edición alemana, estaba claro que ello supondría también un trabajo considerable de actualización de las entradas ya existentes y de introducción de material nuevo. Por supuesto, una tarea de este tipo no se acaba nunca. Es raro y puede considerarse afortunado el editor o autor de libros de ciencias de la vida, especialmente de bioquímica, cuyo material esté totalmente actualizado en el momento de la publicación: el progreso en este campo es muy rápido y no da señales de disminuir. No obstante, en ello radican el reto y el interés de una empresa de este tipo. Hemos comenzado ya a recoger, clasificar y preparar nuevo material con vistas a otra edición.

Nuestra edición difiere de la alemana en que hemos citado algunas referencias bibliográficas nuevas. Se han incluido con parte del material nuevo y esperamos que resulten útiles a aquellos lectores que deseen una información más amplia, adecuada a una obra de este tipo. Donde ha sido posible hemos indicado la numeración EC (Enzyme Comission) de las «Recommendations (1978) of the Nomenclature Commitee of the International Union of Biochemistry on the Nomenclature and Classification of Enzyme-Catalysed Reactions» (publicadas en «Enzyme Nomenclature», Academic Press, 1979).

Pedimos disculpas a aquellos bioquímicos cuyo compuesto, mecanismo o ruta favoritos no se hayan incluido y agradeceríamos las sugerencias acerca de nuevas entradas. También hemos tenido en cuenta que un libro de referencia tiene que mirar asimismo hacia el pasado, defieniendo términos ya en desuso, pero que se encuentran cuando se consulta bibliografía más antigua. A este respecto, serán bienvenidas las sugerencias de nuestros lectores más veteranos.

Finalmente, agradecemos al Dr. Rudolf Weber de Gruyter Publishers su asesoramiento y entusiasmo en la preparación del manuscrito y en la producción de este libro.

Mary Brewer

Menlo Park, California, EE UU

Thomas Scott

Leeds, Yorkshire, Inglaterra 
